\title{
Acute and chronic antibody-mediated rejection in pediatric kidney transplantation
}

\author{
Lars Pape • Jan U. Becker • Stephan Immenschuh • \\ Thurid Ahlenstiel
}

Received: 28 February 2014 /Revised: 28 April 2014 / Accepted: 8 May 2014 / Published online: 28 May 2014

(C) IPNA 2014

\begin{abstract}
Acute antibody-mediated rejection is a diagnostic challenge in renal transplantation medicine. However, it is an important diagnosis to make, since chronic antibody-mediated rejection (CAMR) is the main cause of long-term graft loss. Antibody-mediated rejection is diagnosed by detecting donorspecific antibodies (DSAs) in the blood in combination with observing typical histomorphological signs in kidney biopsy, as described in the Banff classification. Therapy is based on the removal of DSAs by administering intravenous immunoglobulins (IVIGs), plasmapheresis, or immunoadsorption. Reoccurrence of antibodies is diminished by the use of rituximab, increased immunosuppression, and in some cases additional experimental substances. A combination of these techniques has been shown to be successful in the majority of cases of acute and chronic antibody-mediated rejection. Routine DSA monitoring is warranted for early detection of antibody-mediated rejection.
\end{abstract}

Keywords Antibody-mediated rejection · Donor-specific antibodies $\cdot$ Banff classification · Immunoadsorption · Rituximab

\author{
L. Pape $(\bowtie) \cdot$ T. Ahlenstiel \\ Department of Pediatric Nephrology, Hannover Medical School, \\ Carl-Neuberg-Straße 1, 30655 Hannover, Germany \\ e-mail: larspape@t-online.de \\ J. U. Becker \\ Institute of Pathology, Hannover Medical School, Hannover, \\ Germany \\ S. Immenschuh \\ Institute of Transfusion Medicine, Hannover Medical School, \\ Hannover, Germany \\ L. Pape $\cdot$ S. Immenschuh $\cdot$ T. Ahlenstiel \\ Integrated Research and Treatment Center Transplantation, \\ Hannover, Germany
}

\section{Introduction}

After pediatric kidney transplantation, it is important to maintain the right balance between over- and under-immunosuppression. Over-immunosuppression can lead to severe infections and immunosuppressant side effects, such as nephrotoxicity, hirsutism, hypercholesterolemia, and proteinuria, whereas underimmunosuppression can be followed by episodes of acute or chronic antibody-mediated and cellular rejection. The last decades have been very successful regarding the prevention and treatment of acute cellular rejection. However, chronic antibodymediated rejection (CAMR) remains a leading cause of the late loss of kidney transplants in adults [1]. The prevalence of CAMR could even be higher in pediatric nephrology. Since the prognosis for transplant survival is limited once transplant glomerulopathy is present - the main manifestation of CAMR $[2,3]$ - early diagnosis is warranted. Thus, the goal should be to prevent or at least detect acute antibody-mediated rejection early before irreversible damage has occurred.

Histopathological diagnosis of acute antibody-mediated rejection

According to the Banff classification, the most widely used classification scheme for kidney allograft pathology, the diagnosis of acute antibody-mediated rejection is made by a combination of histological findings and the presence of donor specific antibodies (DSAs), none of which is entirely specific in itself [4].

Typical histological features for the diagnosis of acute antibody-mediated rejection according to the current Banff guidelines are shown in Figs. 1 and 2. They include arteritis, as defined by the Banff component $\mathrm{v}$, transplant glomerulitis (Banff component g), peritubular capillaritis (Banff component ptc), microthrombosis without any other cause and C4d positivity of the peritubular capillary endothelium (Banff component C4d) 

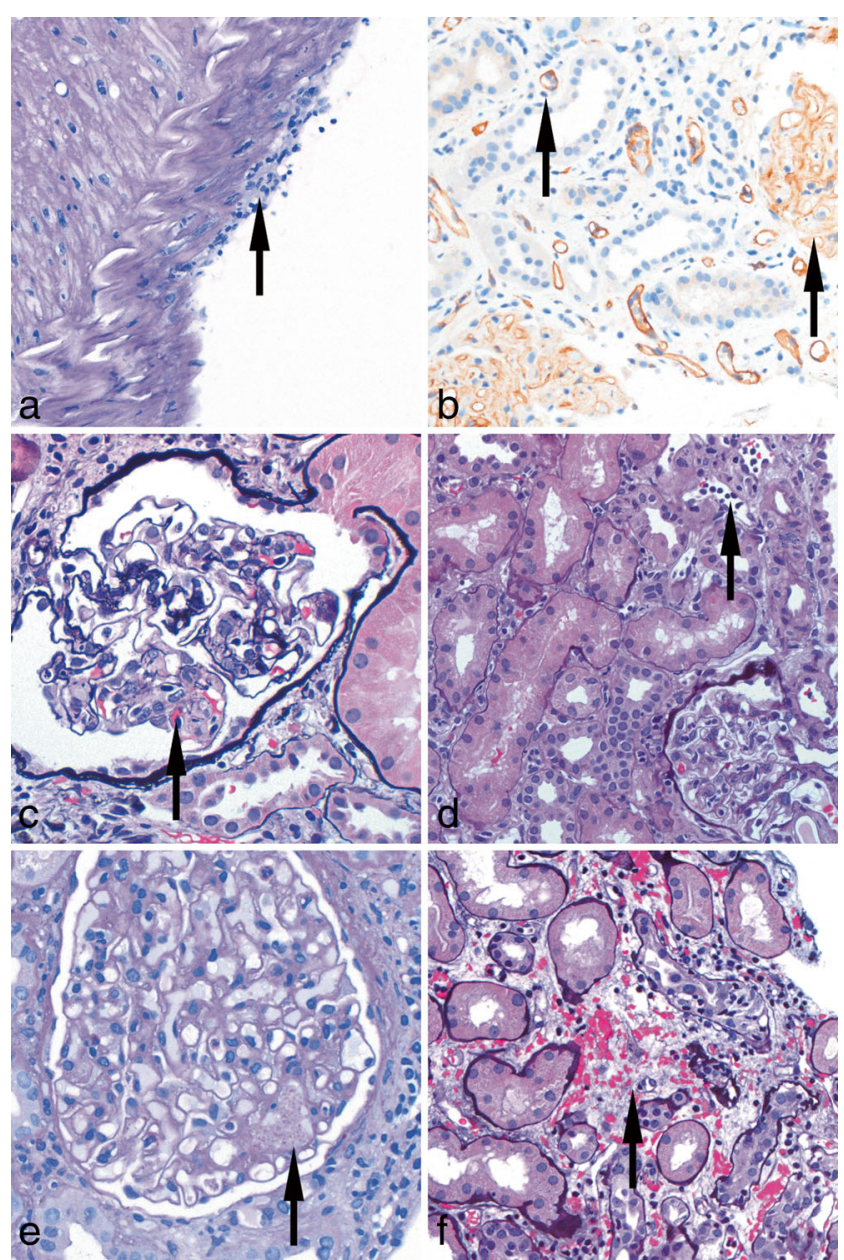

Fig. 1 Histomorphological indicators of acute humoral rejection. a Arterial endothelialitis at the arrow with lymphoid infiltrates underneath swollen endothelium (Banff component v), PAS, original magnification $\times 400$. b C4d-positive endothelium (brown, left arrow) in peritubular capillaries (Banff component $\mathrm{C} 4 \mathrm{~d}$ ) and in glomeruli (right arrow). The latter is currently not considered in the Banff classification. Immunoperoxidase on paraffin-embedded tissue, original magnification $\times 400$. c Transplant glomerulitis with increased content of intracapillary mononuclear cells and swollen endothelium, particularly at the segment marked with an arrow. Jones silver stain, original magnification $\times 400$. d Increased content of mononuclear cells in peritubular capillaries (arrow). Jones silver stain, original magnification $\times 400$. e Glomerular microthrombus (arrow). This particular example consists predominantly of thrombocytes, fibrin-rich forms, and mixed forms can also be observed. PAS, original magnification $\times 600$. $f$ Acute tubulointerstitial hemorrhage (arrow), most likely due to ruptured peritubular capillaries. Jones silver stain, original magnification $\times 400$

[5]. The addition of arteritis, or vascular rejection, to the criteria for acute antibody-mediated rejection was stimulated by a recent cluster analysis in a large cohort of patients from France that identified a humoral component in about two-thirds of patients with arteritis [6]. This and also the recognition of C4d-negative acute antibody-mediated rejection in about $20-40 \%$ of cases remain about the only merits of the new Banff guidelines [5]. The exact definition of the Banff component $g$ (transplant glomerulitis), although long overdue, has been designed to

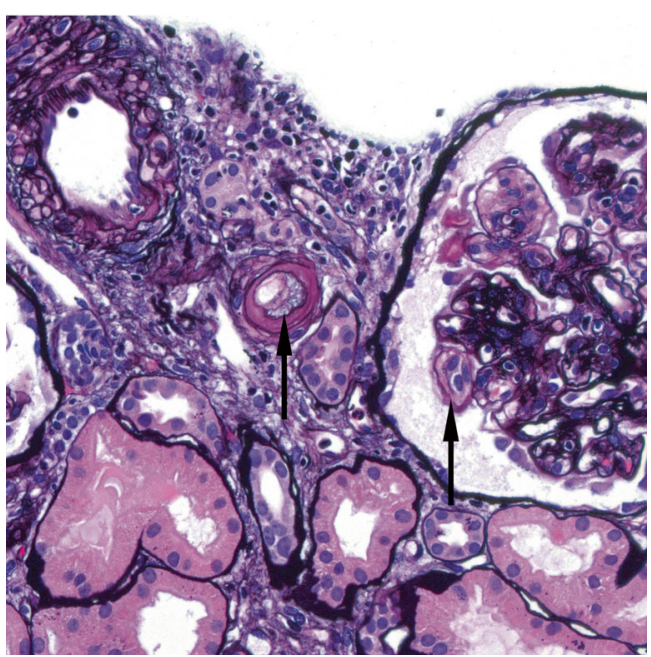

Fig. 2 Histomorphological indicators of chronic humoral rejection. The left arrow highlights intimal expansion (Banff component cv) with foam cells indicative of transplant vasculopathy, the right arrow split glomerular basement membranes (Banff component $\mathrm{cg}$ ) indicative of transplant glomerulopathy. Jones silver stain, original magnification $\times 400$

maximize reproducibility and correlation with mRNA transcriptome changes closely linked with tubulointerstitial rejection on only 47 biopsies; a correlation with outcome was not sought [5]. This and also the change of the threshold between $\mathrm{g} 2$ and $\mathrm{g} 3$ from previously $75 \%[7,8]$ to now $50 \%$ involved glomeruli without announcement is problematic in our view. However, the new consensus guidelines should be used in routine assessment. The excellent work of Randhawa's group [9] for the definition of transplant glomerulitis can still be recommended. Another new and debatable addition to the criteria for acute antibody-mediated rejection is mRNA transcriptome expression analysis [5]. While the addition of novel techniques is certainly desirable, these methods are not available to the entire transplantation community and should prove their usefulness in multi-center studies. Another histological sign of acute antibody-mediated rejection is tubulointerstitial hemorrhage. It was briefly mentioned in the Banff 1997 meeting report and is coded as $\mathrm{v}^{*}$ [7]. It is currently not listed in the defining features of the current Banff guidelines [5]. In the authors' view, it is a rare but specific feature of acute antibody-mediated rejection.

The second cornerstone of the diagnosis of acute antibodymediated rejection is solid-phase serologic testing for DSAs (see below). According to the present Banff guidelines, the serologic and histologic findings should then be taken into consideration to reach a diagnosis of acute antibody-mediated rejection [5]. Details for this reasoning are too complicated to be included in this review.

In summary, the current criteria for the diagnosis of acute antibody-mediated rejection according to the latest update of the Banff classification are still a work in progress and are far from perfect. Future changes are likely and desirable, for example a simplified approach with a scoring system combining histologic and serologic findings of acute antibody-mediated rejection. 
General principles of antibody-mediated rejection treatment

Treatment of antibody-mediated rejection (acute and chronic) is mainly based on two principles: the elimination of the antibodies that cause antibody-mediated rejection and the modulation of adaptive and/or innate immunity to decrease future production of new antibodies. Primarily, intravenous immunoglobulin $\mathrm{G}$ (IVIG) is used as a non-invasive therapy to bind and remove DSAs administered as $1 \mathrm{~g} / \mathrm{kg}$ body weight once weekly for 4 weeks [10], if there is no fast deterioration of renal function. If IVIGs are not effective, plasmapheresis or immunoadsorption are used to remove antibodies directly. Immunoadsorption alone has proven to be a very efficacious method [11] that is most often carried out six times every second day. Before this technique is performed, a Shaldon catheter must be placed. Therefore, the indication has to be set carefully, especially in small children who require anesthesia for this procedure.

Additionally, the anti-CD20 monoclonal antibody rituximab is often administered in a dose of $375 \mathrm{mg} / \mathrm{m}^{2}$ to deplete B cells and B-cell precursors and thereby significantly reduce antibody production through complement-dependent and independent mechanisms [12]. It has to be taken into account that rituximab does not directly target plasma cells that are CD20 negative. The frequency of rituximab courses ranges from once to four times every 4 weeks. Rituximab also directly targets CD20-positive cells in the graft [13]. According to our experience, the density or extent of CD20-positive infiltrates as detectable by immunohistochemistry in the index biopsy is not predictive of response to rituximab (manuscript submitted). It has been shown that rituximab alone does not reduce DSA titers [14], whereas rituximab in combination with IVIGs is effective in treating antibody-mediated rejection [15], despite the fact that the complete mechanism of IVIG action is not well understood [16]. In most cases, immunosuppressive maintenance therapy is increased, i.e., by a change from cyclosporine A to tacrolimus, addition of MMF or mammalian target of rapamycin (mTOR)-inhibitors (eventually as a quadruple therapy), or simple dose increases of the calcineurin-inhibitors.

In difficult cases that do not improve under the therapy described above, experimental therapies have been used with conflicting results. For instance, bortezomib, a proteasome inhibitor, directly inhibits the production of antibodies in plasma cells in vitro [17], which leads to apoptosis of alloantibody-producing plasma cells and consequently should also reduce DSAs at a dose of $1.3 \mathrm{mg} / \mathrm{m}^{2}$. However, one study found that bortezomib alone did not decrease DSA levels [18]. These results are conflicting, and it remains unclear if bortezomib used in combination therapy really leads to a significant decrease in DSAs [19, 20].

Upon binding of DSAs to target cells, the complement system plays an important role. It has been hypothesized that inhibition of the terminal complement complex might also reduce antibody-mediated rejection. Initial reports on the use of the C5-complement-inhibitor eculizumab to treat acute antibody-mediated rejection are promising [21]; however, the results of prospective randomized trials that are currently being carried out are still awaited. Pediatric dosage for this indication is not known, but might be paralleled to treatment of atypical hemolytic uremic syndrome (10-40 kg: $600 \mathrm{mg}$, $>40 \mathrm{~kg}$ : $900 \mathrm{mg}$ ). Eculizumab is even speculated to "revolutionize" the treatment of acute and chronic antibody-mediated rejection [22]. However, given the immense cost of treatment that potentially has to be continued for the entire lifespan of the transplant, this "revolution" might become quite costly. These main treatment principles are summarized in Table 1.

\section{Detection of HLA antibodies}

Although donor-specific HLA- and non-HLA antibodies (DSAs) play a critical role in the pathogenesis of antibodymediated rejection, detection and identification of clinically relevant antibodies is currently intensely discussed. This discussion is primarily driven by the introduction of novel solidphase assay (SPA)-based techniques for serological antibody detection. The complement-dependent lymphocytotoxicity (CDC) assay, which has been the "gold standard" method for HLA antibody detection in kidney transplantation for more than 40 years, has turned out to have major limitations [23, 24]. These limitations include failure to detect noncomplement fixing antibodies, difficulties in distinguishing IgG from IgM antibody isotypes, and the imprecision in determining DSAs. In contrast, SPA-based techniques, in particular the Luminex test, are markedly more sensitive in the detection of HLA antibodies in comparison to the CDC [23]. The recent widespread application of SPA-based tests in clinical practice has confirmed the higher sensitivity of these diagnostic methods. Conflictingly, however, a growing number of studies in kidney transplantation patients have also shown that only a portion of Luminex-detectable HLA antibodies appear to cause antibody-mediated rejection [25-27]. This differentiation between clinically relevant and irrelevant DSAs is a major challenge, both before and after kidney

Table 1 Two treatment principles of antibody-mediated rejection and treatment options in each category

\begin{tabular}{ll}
\hline Antibody depletion & $\begin{array}{c}\text { Decrease antibody production/ } \\
\text { prevent antibody-mediated rejection } \\
\text { Change basic immunosuppressive therapy } \\
\text { (i.e., tacrolimus instead of CsA, addition of } \\
\text { IVIG }\end{array}$ \\
& $\begin{array}{l}\text { Rituximab } \\
\text { Plasmapheresis }\end{array}$ \\
Immunoadsorption & Bortezomib (?) \\
& Eculizumab (?) \\
\hline
\end{tabular}

$I V I G$ intravenous immunoglobulins 
transplantation [24, 27, 28]. For example, the pathogenetic roles of different Ig subclasses or those of complement- and non-complement-fixing DSAs in antibody-mediated rejection are controversially discussed [29]. On the one hand, complement-fixation is considered to be a major criterion for the pathogenicity of HLA antibodies in antibody-mediated rejection and has recently been confirmed in a large study with more than 1,000 patients [30]. On the other hand, accumulating evidence indicates that non-complement-fixing antibodies are also crucially involved in graft rejection via direct endothelial cell activation [31]. Independently, non-HLA antibodies have been demonstrated to play a major role in the pathogenesis of antibody-mediated rejection [32-35]. In particular, non-HLA antibodies against endothelial antigens such as the major histocompatibility complex class I-related chain A (MICA) cause antibody-mediated rejection in transplantation patients [36, 37]. Moreover, anti-endothelial cell antibodies against other known endothelial surface antigens such as the angiotensin II type 1-receptor, vimentin and collagen V or against unknown antigens have been implicated in antibodymediated rejection after kidney transplantation [32, 34]. For a comprehensive overview of the role of antibodies in clinical decision-making for kidney transplantation, we refer to recently published consensus guidelines, which summarize various critical aspects in HLA and non-HLA antibody detection [38]. It is also important to note that strong efforts are currently underway to standardize the detection methods for antibodies by SPA-based methods for a better comparibility of antibody testing results in different laboratories [39].

HLA antibodies are predominantly detected by LABScreen Mixed assays and the LABScreen Single Antigen assay. As a screening test, mixed antigen beads are used in many centers. In the case of positive results, the single antigen test should be performed to confirm the development of DSAs. Other centers only carry out the more expensive single antigen test. The amount of DSAs is detected as the mean fluorescence intensity (MFI). There is an ongoing discussion about the valid threshold levels that define antibody-mediated rejection. Most often, a mean fluorescence intensity (MFI) $>1,000$ is considered as positive for HLA antibodies [40]. The British Society of Transplantation has even suggested testing for DSAs every 3 months after kidney and pancreas transplantation [40]. The rates of DSAs in routine monitoring have been published to be between 2.5 and $24 \%$ [41, 42]. Especially high HLA class II antibody levels are related to an increased risk of developing transplant glomerulopathy and C4d deposits in peritubular capillaries [43]. The diagnostic role of measuring C1q-fixing DSAs is still unclear [44], but might help to distinguish between clinically relevant and nonrelevant DSAs. The Transplantation Society has published guidelines for the detection of DSA after kidney transplantation that should be used as a basis for local decisions [45].
Acute antibody-mediated rejection

Acute antibody-mediated rejection in children is most often observed within the first weeks after transplantation. However, it can be observed any time after transplantation, often after periods of non-adherence to immunosuppressive therapy.

In case of an impairment of graft function, a kidney biopsy should be performed in combination with serological detection of DSAs. If acute antibody-mediated rejection is detected, a fast increase in immunosuppressive therapy is advisable. Most often, treatment begins with steroid pulse therapy (six pulses with $300 \mathrm{mg} / \mathrm{m}^{2}$ daily) followed by antibody removal via immunoadsorption or plasmapheresis six times every second day and rituximab administration once with $375 \mathrm{mg} / \mathrm{m}^{2}$. Some cumulative case reports published by Kranz et al. demonstrate that this combination therapy is successful in most cases and leads to a reversal of graft dysfunction [46]. In adults, similar cases have been successfully treated with the complement C5 inhibitor eculizumab [21]. Several prospective trials on acute antibody-mediated rejection in adults, who are predominantly presensitized high-risk-patients, are being carried out. The results of these trials are awaited before this therapy can become a standard treatment in children with acute antibodymediated rejection. Continuous DSA monitoring after the first episode of acute antibody-mediated rejection is a prerequisite for early intervention and prevention of a second episode.

To avoid acute antibody-mediated rejection in the early phase after transplantation, pretransplant desensitization strategies (most often including IVIGs, rituximab, and immunoadsorption) should be considered. These strategies reduce panel reactive antibodies or even "future" DSAs if transplantation against "forbidden antigens" is planned [47]. A special entity is ABO-incompatible pediatric kidney transplantation, where, if special protocols are applied, antibodymediated rejection can be avoided [48].

\section{Chronic antibody-mediated rejection (CAMR)}

Until the BANFF 2005 meeting, chronic changes in transplanted kidneys had been summarized as chronic allograft nephropathy [49], with interstitial fibrosis and tubular atrophy as the surrogate markers in biopsies [50]. However, it took some time before this diagnosis was integrated into routine care. In 2009, El-Zoghby et al. differentiated the reasons for chronic transplant loss. These authors identified CAMR as a main cause in adults [1]. The same has been shown in children [51].

After kidney transplantation, interstitial fibrosis and tubular atrophy (IF/TA) develop within the first 12 months as early changes [52]. Late changes, such as microvascular and glomerular damage, most often occur in the following years [49]. In 2011, Sellares et al. showed that IF/TA alone is not a risk factor for future loss of graft function. In late allograft biopsies, 
Fig. 3 Algorithm for diagnosis and treatment of chronic antibody-mediated rejection according to Billing et al. [63]

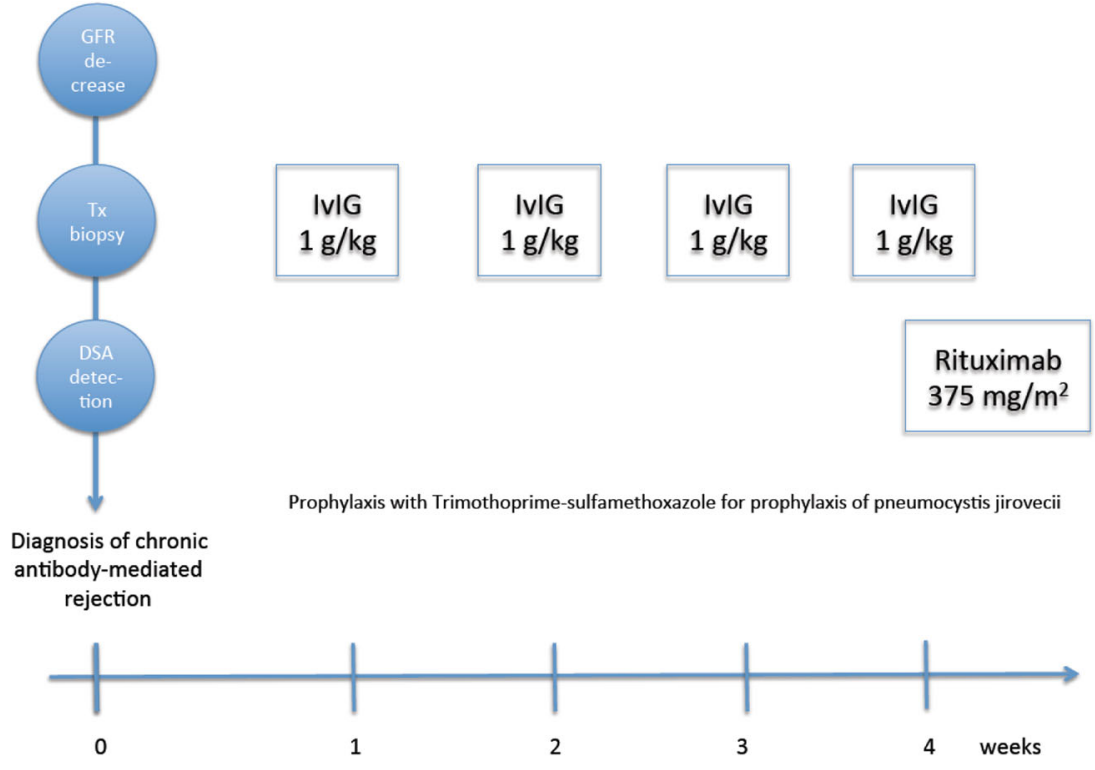

Rituximab $375 \mathrm{mg} / \mathrm{m}^{2}$

Prophylaxis with Trimothoprime-sulfamethoxazole for prophylaxis of pneumocystis jirovecii graft survival $[60,61]$. The most important trial studying the treatment of CAMR in children was carried out by Toenshoff and Billing. Children with chronic, active antibody-mediated rejection were treated with four weekly doses of $1 \mathrm{~g} / \mathrm{kg}$ IVIGs followed by administration of a single dose of rituximab of $375 \mathrm{mg} / \mathrm{m}^{2}$ (Fig. 3). With this regimen, the mean decrease in the glomerular filtration rate (GFR) of $25 \mathrm{ml} / \mathrm{min} / 1.73 \mathrm{~m}^{2}$ observed in the 6 months before treatment could be reversed to an increase of $21 \mathrm{ml} / \mathrm{min} / 1.73 \mathrm{~m}^{2}$ in the following half year. Only two of the six patients did not respond to this regimen [62]. In a larger trial with 20 patients and a 2-year follow-up, the researchers confirmed that the decrease of GFR could be significantly reduced over 2 years by this combination treatment, and the response rate was $70 \%$. This result was associated with a $61 \%$ decrease in HLA class I antibodies and a $63 \%$ decrease in HLA class II antibodies [63]. A study in adults showed that a combination of this regimen with plasmapheresis therapy can further improve these results [64]. There are conflicting reports on whether additional therapy with the proteasome inhibitor bortezomib provides a further beneficial effect [19]. However, bortezomib alone was not effective in treating CAMR [20].

\section{Conclusions}

Acute antibody-mediated rejection is an entity that can occur at any point in time after transplantation. The diagnosis can be made by renal biopsy and the detection of DSAs in blood. The treatment of acute antibody-mediated rejection is straightforward with immunoadsorption/plasmapheresis to remove antibodies in combination with IVIGs, rituximab, and an increase in basic immunosuppression. If detected and treated early enough, then the prognosis is good. 
CAMR is the main cause of long-term graft loss. The diagnosis with transplant glomerulopathy and/or transplant vasculopathy as criteria is straightforward. Nevertheless, many cases are a therapeutic dilemma, because signs of activity (DSAs, C4d-positivity, transplant glomerulitis, or peritubular capillaritis) are often scarce or absent. Moreover, when CAMR is diagnosed, it is often quite late for treatment, because the prognosis at this stage is guarded. Nevertheless, treatment with IVIGs and rituximab with or without plasmapheresis/immunoadsorption can halt loss of graft function in the majority of cases. Thus, it is of utmost importance to prevent acute antibody-mediated rejection, which is often caused by non-adherence; early diagnosis can prevent irreversible structural changes in the transplant.

\section{Key summary points}

1. Acute antibody-mediated rejection can be diagnosed by detection of DSAs and renal biopsy and is treated with a combination of immunoadsorption/plasmapheresis, rituximab, and IVIGs.

2. DSAs suggest the diagnosis of CAMR.

3. Treatment of CAMR with IVIGs and rituximab improves graft function in $>70 \%$ of cases.

4. Under-immunosuppression must be avoided to prevent CAMR.

\section{Multiple-choice questions (answers are provided following the references below)}

1. The detection of DSAs in a pediatric kidney recipient

a. is always associated with antibody-mediated rejection

b. is always associated with $\mathrm{C} 4 \mathrm{~d}$ detection in kidney biopsy

c. should primarily be treated with immunoadsorption/ plasmapheresis

d. is suspicious for chronic under-immunosuppression

2. Treatment of chronic antibody-mediated rejection is not performed with
a. IVIGs
b. Bortezomib
c. Methotrexate
d. Rituximab

3. Steroid-free immunosuppression

a. increases the number of patients with DSA detection

b. leads to higher MFI values in case of DSA detection c. increases the number of patients with chronic humoral rejection

d. is not associated with an increased risk of HLA antibody formation

4. Which is the following is not a histologic feature of antibody-mediated rejection?
a. glomerulitis
b. tubulitis
c. IF/TA
d. hyalinosis of small arteries

5. The worst outcome is associated with
a. IF/TA in kidney biopsy
b. Inflammation in kidney biopsy
c. IF/TA and inflammation in kidney biopsy
d. IF/TA and C4d detection in kidney biopsy

\section{References}

1. El-Zoghby ZM, Stegall MD, Lager DJ, Kremers WK, Amer H, Gloor JM, Cosio FG (2009) Identifying specific causes of kidney allograft loss. Am J Transplant 9:527-535

2. Perkowska-Ptasinska A, Ciszek M, Chmura A, Galazka Z, Paczek L, Durlik M (2009) Transplant glomerulopathy: clinical and pathological correlations. Transplant Proc 41:141-149

3. John R, Konvalinka A, Tobar A, Kim SJ, Reich HN, Herzenberg AM (2010) Determinants of long-term graft outcome in transplant glomerulopathy. Transplantation 90:757-764

4. Sis B, Mengel M, Haas M, Colvin RB, Halloran PF, Racusen LC, Solez K, Baldwin WM III, Bracamonte ER, Broecker V, Cosio F, Demetris AJ, Drachenberg C, Einecke G, Gloor J, Glotz D, Kraus E, Legendre C, Liapis H, Mannon RB, Nankivell BJ, Nickeleit V, Papadimitriou JC, Randhawa P, Regele H, Renaudin K, Rodriguez ER, Seron D, Seshan S, Suthanthiran M, Wasowska BA, Zachary A, Zeevi A (2010) Banff '09 meeting report: antibody mediated graft deterioration and implementation of Banff working groups. Am J Transplant 10:464-471

5. Haas M, Sis B, Racusen LC, Solez K, Glotz D, Colvin RB, Castro MC, David DS, David-Neto E, Bagnasco SM, Cendales LC, Cornell LD, Demetris AJ, Drachenberg CB, Farver CF, Farris AB III, Gibson IW, Kraus E, Liapis H, Loupy A, Nickeleit V, Randhawa P, Rodriguez ER, Rush D, Smith RN, Tan CD, Wallace WD, Mengel M, Banff meeting report writing committee (2014) Banff 2013 meeting report: inclusion of $\mathrm{c} 4 \mathrm{~d}$-negative antibody-mediated rejection and antibody-associated arterial lesions. Am J Transplant 14:272-283

6. Lefaucheur C, Loupy A, Vernerey D, Duong-Van-Huyen JP, Suberbielle C, Anglicheau D, Verine J, Beuscart T, Nochy D, Bruneval P, Charron D, Delahousse M, Empana JP, Hill GS, Glotz D, Legendre C, Jouven X (2013) Antibody-mediated vascular rejection of kidney allografts: a population-based study. Lancet 381:313-319

7. Racusen LC, Solez K, Colvin RB, Bonsib SM, Castro MC, Cavallo T, Croker BP, Demetris AJ, Drachenberg CB, Fogo AB, Furness P, Gaber LW, Gibson IW, Glotz D, Goldberg JC, Grande J, Halloran PF, Hansen HE, Hartley B, Hayry PJ, Hill CM, Hoffman EO, Hunsicker 
LG, Lindblad AS, Yamaguchi Y (1999) The Banff 97 working classification of renal allograft pathology. Kidney Int 55:713-723

8. Solez K, Racusen LC (2013) The Banff classification revisited. Kidney Int 83:201-206

9. Batal I, Lunz JG III, Aggarwal N, Zeevi A, Sasatomi E, Basu A, Tan H, Shapiro R, Randhawa P (2010) A critical appraisal of methods to grade transplant glomerulitis in renal allograft biopsies. Am J Transplant 10:2442-2452

10. Jordan SC, Toyoda M, Kahwaji J, Vo AA (2011) Clinical aspects of intravenous immunoglobulin use in solid organ transplant recipients. Am J Transplant 11:196-202

11. Böhmig GA, Wahrmann M, Regele H, Exner M, Robl B, Derfler K, Soliman T, Bauer P, Müllner M, Druml W (2007) Immunoadsorption in severe C4d-positive acute kidney allograft rejection: a randomized controlled trial. Am J Transplant 7:117-121

12. Salama AD, Pusey CD (2006) Drug insight: rituximab in renal disease and transplantation. Nat Clin Pract Nephrol 2:221-230

13. Steinmetz OM, Lange-Husken F, Turner JE, Vernauer A, Helmchen U, Stahl RA, Thaiss F, Panzer U (2007) Rituximab removes intrarenal B cell clusters in patients with renal vascular allograft rejection. Transplantation 84:842-850

14. Takemoto SK, Zeevi A, Feng S, Colvin RB, Jordan S, Kobashigawa J, Kupiec-Weglinski J, Matas A, Montgomery RA, Nickerson P, Platt JL, Rabb H, Thistlethwaite R, Tyan D, Delmonico FL (2004) National conference to assess antibody-mediated rejection in solid organ transplantation. Am J Transplant 4:1033-1041

15. Hong YA, Kim HG, Choi SR, Sun IO, Park HS, Chung BH, Choi BS, Park CW, Kim YS, Yang CW (2012) Effectiveness of rituximab and intravenous immunoglobulin therapy in renal transplant recipients with chronic active antibody-mediated rejection. Transplant Proc 44: 182-184

16. Jordan SC, Toyoda M, Vo AA (2011) Regulation of immunity and inflammation by intravenous immunoglobulin: relevance to solid organ transplantation. Expert Rev Clin Immunol 7:341-348

17. Clatworthy MR (2011) Targeting B cells and antibody in transplantation. Am J Transplant 11:1359-1367

18. Sberro-Soussan R, Zuberl J, Suberbielle-Boissel C, Legendre C (2010) Bortezomib alone fails to decrease donor specific anti-HLA antibodies: even after one year post-treatment. Clin Transpl 2010: 409-414

19. Everly MJ, Everly JJ, Susskind B, Brailey P, Arend LJ, Alloway RR, Roy-Chaudhury P, Govil A, Mogilishetty G, Rike AH, Cardi M, Wadih G, Brown E, Tevar A, Woodle ES (2009) Proteasome inhibition reduces donor-specific antibody levels. Transplant Proc 41:105-107

20. Sberro-Soussan R, Zuber J, Suberbielle-Boissel C, Candon S, Martinez F, Snanoudj R, Rabant M, Pallet N, Nochy D, Anglicheau D, Leruez M, Loupy A, Thervet E, Hermine O, Legendre C (2010) Bortezomib as the sole post-renal transplantation desensitization agent does not decrease donor-specific anti-HLA antibodies. Am J Transplant 10:681-686

21. Gonzalez-Roncero F, Suner M, Bernal G, Cabello V, Toro M, Pereira P, Angel Gentil M (2012) Eculizumab treatment of acute antibodymediated rejection in renal transplantation: case reports. Transplant Proc 44:2690-2694

22. Legendre C, Sberro-Soussan R, Zuber J, Rabant M, Loupy A, Timsit MO, Anglicheau D (2013) Eculizumab in renal transplantation. Transplant Rev (Orlando) 27:90-92

23. Tait BD (2009) Solid phase assays for HLA antibody detection in clinical transplantation. Curr Opin Immunol 21:573-577

24. Claas FH (2010) Clinical relevance of circulating donor-specific HLA antibodies. Curr Opin Organ Transplant 15:462-466

25. Susal C, Ovens J, Mahmoud K, Dohler B, Scherer S, Ruhenstroth A, Tran TH, Heinold A, Opelz G (2011) No association of kidney graft loss with human leukocyte antigen antibodies detected exclusively by sensitive Luminex single-antigen testing: a collaborative transplant study report. Transplantation 91:883-887
26. Archdeacon P, Chan M, Neuland C, Velidedeoglu E, Meyer J, Tracy L, Cavaille-Coll M, Bala S, Hernandez A, Albrecht R (2011) Summary of FDA antibody-mediated rejection workshop. Am J Transplant 11:896-906

27. Gombos P, Opelz G, Scherer S, Morath C, Zeier M, Schemmer P, Susal C (2013) Influence of test technique on sensitization status of patients on the kidney transplant waiting list. Am J Transplant 13:2075-2082

28. Bradley JA, Baldwin WM, Bingaman A, Ellenrieder C, Gebel HM, Glotz D, Kirk AD (2011) Antibody-mediated rejection-an ounce of prevention is worth a pound of cure. Am J Transplant 11:1131-1139

29. Bohmig GA, Bartel G, Wahrmann M (2008) Antibodies, isotypes and complement in allograft rejection. Curr Opin Organ Transplant $13: 411-418$

30. Loupy A, Lefaucheur C, Vernerey D, Prugger C, Duong van Huyen JP, Mooney N, Suberbielle C, Fremeaux-Bacchi V, Mejean A, Desgrandchamps F, Anglicheau D, Nochy D, Charron D, Empana JP, Delahousse M, Legendre C, Glotz D, Hill GS, Zeevi A, Jouven X (2013) Complement-binding anti-HLA antibodies and kidneyallograft survival. N Engl J Med 369:1215-1226

31. Naemi FM, Carter V, Kirby JA, Ali S (2013) Anti-donor HLA class I antibodies: pathways to endothelial cell activation and cell-mediated allograft rejection. Transplantation 96:258-266

32. Sumitran-Holgersson S (2008) Relevance of MICA and other non-HLA antibodies in clinical transplantation. Curr Opin Immunol 20:607-613

33. Zou Y, Stastny P (2009) The role of major histocompatibility complex class I chain-related gene A antibodies in organ transplantation. Curr Opin Organ Transplant 14:414-418

34. Dragun D, Philippe A, Catar R (2012) Role of non-HLA antibodies in organ transplantation. Curr Opin Organ Transplant 17:440-445

35. Opelz G, Collaborative Transplant Study (2005) Non-HLA transplantation immunity revealed by lymphocytotoxic antibodies. Lancet 365:1570-1576

36. Zou Y, Stastny P, Susal C, Dohler B, Opelz G (2007) Antibodies against MICA antigens and kidney-transplant rejection. N Engl J Med 357:1293-1300

37. Zhang Q, Cecka JM, Gjertson DW, Ge P, Rose ML, Patel JK, Ardehali A, Kobashigawa JA, Fishbein MC, Reed EF (2011) HLA and MICA: targets of antibody-mediated rejection in heart transplantation. Transplantation 91:1153-1158

38. Tait BD, Susal C, Gebel HM, Nickerson PW, Zachary AA, Claas FH, Reed EF, Bray RA, Campbell P, Chapman JR, Coates PT, Colvin RB, Cozzi E, Doxiadis II, Fuggle SV, Gill J, Glotz D, Lachmann N, Mohanakumar T, Suciu-Foca N, Sumitran-Holgersson S, Tanabe K, Taylor CJ, Tyan DB, Webster A, Zeevi A, Opelz G (2013) Consensus guidelines on the testing and clinical management issues associated with HLA and non-HLA antibodies in transplantation. Transplantation 95:19-47

39. Reed EF, Rao P, Zhang Z, Gebel H, Bray RA, Guleria I, Lunz J, Mohanakumar T, Nickerson P, Tambur AR, Zeevi A, Heeger PS, Gjertson D (2013) Comprehensive assessment and standardization of solid phase multiplex-bead arrays for the detection of antibodies to HLA-drilling down on key sources of variation. Am J Transplant 13: 3050-3051

40. Howell WM, Harmer A, Briggs D, Dyer P, Fuggle SV, Martin S, Sinnott P, Smith J, Taylor CJ, Vaughan R, British Society for Histocompatibility \& Immunogenetics; British Transplantation Society (2010) British Society for Histocompatibility \& Immunogenetics and British Transplantation Society guidelines for the detection and characterisation of clinically relevant antibodies in allotransplantation. Int J Immunogenet 37:435-437

41. Gill JS, Landsberg D, Johnston O, Shapiro RJ, Magil AB, Wu V, Tinckam K, Keown P (2010) Screening for de novo anti-human leukocyte antigen antibodies in nonsensitized kidney transplant recipients does not predict acute rejection. Transplantation 89:178-184

42. Piazza A, Poggi E, Borrelli L, Servetti S, Monaco PI, Buonomo O, Valeri M, Torlone N, Adorno D, Casciani CU (2001) Impact of 
donor-specific antibodies on chronic rejection occurrence and graft loss in renal transplantation: posttransplant analysis using flow cytometric techniques. Transplantation 71:1106-1112

43. Issa N, Cosio FG, Gloor JM, Sethi S, Dean PG, Moore SB, DeGoey S, Stegall MD (2008) Transplant glomerulopathy: risk and prognosis related to anti-human leukocyte antigen class II antibody levels. Transplantation 86:681-685

44. Crespo M, Torio A, Mas V, Redondo D, Perez-Saez MJ, Mir M, Faura A, Guerra R, Montes-Ares O, Checa MD, Pascual J (2013) Clinical relevance of pretransplant anti-HLA donor-specific antibodies: does C1q-fixation matter? Transpl Immunol 29:28-33

45. Wettstein D, Opelz G, Susal C (2014) HLA antibody screening in kidney transplantation: current guidelines. Langenbecks Arch Surg 399:415-420

46. Kranz B, Kelsch R, Kuwertz-Broking E, Brocker V, Wolters HH, Konrad M (2011) Acute antibody-mediated rejection in paediatric renal transplant recipients. Pediatr Nephrol 26:1149-1156

47. Otukesh H, Hoseini R, Rahimzadeh N (2012) Treatment update of sensitized pediatric kidney transplant recipients: a review. Exp Clin Transplant 10:523-530

48. Tyden G, Kumlien G, Berg UB (2011) ABO-incompatible kidney transplantation in children. Pediatr Transplant 15:502-504

49. Nankivell BJ, Borrows RJ, Fung CL, O'Connell PJ, Allen RD, Chapman JR (2003) The natural history of chronic allograft nephropathy. N Engl J Med 349:2326-2333

50. Kanzelmeyer NK, Ahlenstiel T, Drube J, Froede K, Kreuzer M, Broecker V, Ehrich JH, Melk A, Pape L (2010) Protocol biopsydriven interventions after pediatric renal transplantation. Pediatr Transplant 14:1012-1018

51. Ginevri F, Nocera A, Comoli P, Innocente A, Cioni M, Parodi A, Fontana I, Magnasco A, Nocco A, Tagliamacco A, Sementa A, Ceriolo P, Ghio L, Zecca M, Cardillo M, Garibotto G, Ghiggeri GM, Poli F (2012) Posttransplant de novo donor-specific hla antibodies identify pediatric kidney recipients at risk for late antibodymediated rejection. Am J Transplant 12:3355-3362

52. Dart AB, Schall A, Gibson IW, Blydt-Hansen TD, Birk PE (2010) Patterns of chronic injury in pediatric renal allografts. Transplantation 89:334-340

53. Sellares J, de Freitas DG, Mengel M, Sis B, Hidalgo LG, Matas AJ, Kaplan B, Halloran PF (2011) Inflammation lesions in kidney transplant biopsies: association with survival is due to the underlying diseases. Am J Transplant 11:489-499

54. Park WD, Griffin MD, Cornell LD, Cosio FG, Stegall MD (2010) Fibrosis with inflammation at one year predicts transplant functional decline. J Am Soc Nephrol 21:1987-1997

55. Sis B, Campbell PM, Mueller T, Hunter C, Cockfield SM, Cruz J, Meng C, Wishart D, Solez K, Halloran PF (2007) Transplant glomerulopathy, late antibody-mediated rejection and the $\mathrm{ABCD}$ tetrad in kidney allograft biopsies for cause. Am J Transplant 7: $1743-1752$

56. Cosio FG, Gloor JM, Sethi S, Stegall MD (2008) Transplant glomerulopathy. Am J Transplant 8:492-496

57. Lee PC, Zhu L, Terasaki PI, Everly MJ (2009) HLA-specific antibodies developed in the first year posttransplant are predictive of chronic rejection and renal graft loss. Transplantation 88:568-574

58. Verghese PS, Smith JM, McDonald RA, Schwartz SM, Nelson KA, Warner PR (2010) Impaired graft survival in pediatric renal transplant recipients with donor-specific antibodies detected by solid-phase assays. Pediatr Transplant 14:730-734

59. Chaudhuri A, Ozawa M, Everly MJ, Ettenger R, Dharnidharka V, Benfield M, Mathias R, Portale A, McDonald R, Harmon W, Kershaw D, Vehaskari VM, Kamil E, Baluarte HJ, Warady B, Li L, Sigdel TK, Hsieh SC, Dai H, Naesens M, Waskerwitz J, Salvatierra O Jr, Terasaki PI, Sarwal MM (2013) The clinical impact of humoral immunity in pediatric renal transplantation. J Am Soc Nephrol 24: 655-664

60. Everly MJ, Everly JJ, Arend LJ, Brailey P, Susskind B, Govil A, Rike A, Roy-Chaudhury P, Mogilishetty G, Alloway RR, Tevar A, Woodle ES (2009) Reducing de novo donor-specific antibody levels during acute rejection diminishes renal allograft loss. Am J Transplant 9: 1063-1071

61. Everly MJ, Rebellato LM, Ozawa M, Briley KP, Catrou PG, Haisch CE, Terasaki PI (2010) Beyond histology: lowering human leukocyte antigen antibody to improve renal allograft survival in acute rejection. Transplantation 89:962-967

62. Billing H, Rieger S, Ovens J, Susal C, Melk A, Waldherr R, Opelz G, Tonshoff B (2008) Successful treatment of chronic antibodymediated rejection with IVIG and rituximab in pediatric renal transplant recipients. Transplantation 86:1214-1221

63. Billing H, Rieger S, Susal C, Waldherr R, Opelz G, Wuhl E, Tonshoff B (2012) IVIG and rituximab for treatment of chronic antibodymediated rejection: a prospective study in paediatric renal transplantation with a 2-year follow-up. Transpl Int 25:1165-1173

64. Lefaucheur C, Nochy D, Andrade J, Verine J, Gautreau C, Charron D, Hill GS, Glotz D, Suberbielle-Boissel C (2009) Comparison of combination plasmapheresis/IVIg/anti-CD20 versus high-dose IVIg in the treatment of antibody-mediated rejection. Am J Transplant 9: $1099-1107$

\section{Answers to the questions:}

$1 d, 2 c, 3 d, 4 b, 5 c$ 